іiї громадянської активності заради формування згуртованої спільноти громадян, здатних до активної творчої співучасті у гармонійному, збалансованому та сталому розвитку держави.

\title{
Література:
}

1. Гайдук І.С. Теоретико-методологічні аспекти поняття «людський потенціал» / I.C. Гайдук // Економічний вісник університету. 2016. Вип. 30(1). С. 113-120. URL: http://nbuv.gov.ua/UJRN/ecvu_2016_30\% $281 \% 29 \_18$

2. Іляш О. І., Блохін П. В. Майбутнє $\mathrm{hr}$ менеджменту: тенденції, ризики, мотивація. Ефективна економіка. 2018. № 10. URL: http://www.economy.nayka.com.ua/?op $=1 \& z=6575$

3. Майбутнє ринку праці. Протиборство тенденцій, які будуть формувати робоче середовище в 2030 році. URL: https://www.pwc.com/ ua/uk/survey/2018/workforce-of-the-future-ukr.pdf

4. Про рішення Ради національної безпеки і оборони України від 14 травня 2021 року «Про Стратегію людського розвитку» : Указ Президента України від 2 червня 2021 року № 225/2021. URL: https://www.president.gov.ua/documents/2252021-39073

5. Уряд схвалив проект Указу Президента України про Стратегію людського розвитку. URL: https://www.kmu.gov.ua/news/uryad-shvalivproekt-ukazu-prezidenta-ukrayini-pro-strategiyu-lyudskogo-rozvitku

\section{DOI https://doi.org/10.30525/978-9934-26-177-0-18}

\section{ЦИФРОВІЗАЦІЯ ЯК СПОСІБ ПОСИЛЕННЯ ПУБЛІЧНОСТІ ВЛАДИ В УКРАЇНІ}

\author{
Стукан Т. М. \\ асистент кафедри публічного управління і права \\ Херсонського державного аграрно-економічного університету \\ м. Херсон, Украӥна
}

Застосування процесів цифровізації в органах центральної та виконавчої влади на сьогодні є трендом, адже це $є$ драйвером сталого розвитку соціально-економічних відносин у суспільстві. Пріоритетним для влади є зробити спілкування громадян і бізнесу 3 державою зручним, прозорим та людяним, а можливо це зробити через створення 
«цифрової держави». Прояв цифрових трансформацій в сфері публічної влади можна спостерігати через організацію діяльності мережі Центрів надання адміністративних послуг (далі - ЦНАП). 32013 р. в Україні розпочався активний процес відкриття Центрів надання адміністративних послуг на виконання Закону України «Про адміністративні послуги» [1]. ЦНАПи - це місця (будівлі, приміщення, орган влади), де громадяни можуть отримати максимально необхідний набір адміністративних послуг у комфортних умовах. В Україні Центри створюють через одну із двох організаційно-правових форм: зі статусом постійно діючого робочого органу та як структурний підрозділ при виконавчому органі відповідної ради. На сьогодні право створювати ЦНАПи в Україні надано всім громадам без виключення, що в чергове підтверджує суть здійснення публічної влади, яка бере на себе відповідальності за створення якісних умов обслуговування громадян.

Головним завданням створених Центрів є підвищення доступності та якості надання адміністративних послуг у найкоротший строк, за спрощеною процедурою та за мінімальної кількості відвідувань суб'єктів звернень [2].

У національному реєстрі Центрів надання адміністративних послуг зареєстровано 2739, серед них - 1224 віддалених робочих місця, 984 ЦНАП та Дія Центрів, 105 територіальних підрозділів та 24 мобільних ЦНАП, вони покривають своїми послугами всю територію України, порівнюючи 32014 р., то тільки громадяни 11 регіонів, що охоплювало 14 міст могли отримати адміністративні послуги через такі Центри. У 2017 р. кількість Центрів зросла та налічувала 713 ЦНАПів. Сьогодні Центри створюються в кожному районному центрі, територіальній громаді, місті і в великих селах. У 2020 р. таких точок доступу стало доступно 1286, що вдвічі більше ніж у 2019 p.

Розширенню мережі Центрів по Україні сприяло активне впровадження реформ децентралізації, коли територіальні громади почали отримувати широкі повноваження, ресурси і брати на себе відповідальність, що стало стимулом до того, що в громадах почали відкриватись ЦНАПи. Враховуючи розширення мережі Центрів та кількості адміністративних послуг, що ними надаються можна говорити, що влада стає більш публічною та доступною для кожного громадянина. Лідерами серед областей в Україні по створенню точок доступу 3 надання адміністративних послуг $є$ Івано-Франківська (233 точок доступу), Волинська (145) та Київська (149), в той же час Херсонська область має всього 22 Центри. Завдяки Центрам 70 
адміністративних послуг для громадян надаються послуги у сучасному, цифровому та прозорому форматі $[2,3]$.

Перевагами розвитку мережі ЦНАП в Україні $\epsilon$ те, що для громадян: адміністративні послуги стали ближчими; з'явилися нові робочі місця в громадах; зменшилась кількість черг завдяки новим точкам доступу до отримання адміністративних послуг та їх систематичному збільшенню; у найвіддаленіших населених пунктах 3'явилася можливість отримувати державні послуги поруч із домом.

Для зручності громадян та покращення якості надання адміністративних послуг на початку 2021 року Міністерством цифрової трансформації створено та введено в дію Національну веб-платформу центрів надання адміністративних послуг (Платформу Центрів Дія). Скориставшись цією платформою можна отримати: інформацію про роботу ЦНАПів та доступні через них адміністративні послуги; знайти на мапі найближчий Центр та записатися на прийом; оцінити якість послуг, надати відгуки, скарги, ідеї або пропозиції; залишити заявку на працевлаштування у ЦНАПі. Онлайн майданчик $є$ також корисним i для самих працівників Центрів, які можуть через нього проходити онлайн-курси від фахівців; отримувати роз'яснення та рекомендації щодо роботи; користуватися бібліотекою корисних матеріалів; вивчати найкращі практики; одержувати актуальні шаблони та зразки документів. Через онлайн майданчик Центрів Дія відвідувачі можуть також отримати перелік основних сервісів, що надаються ЦНАПом, який громадянин бажає відвідати, а це широкий перелік адміністративних послуг, консультації щодо отримання онлайн-послуг, про наявність місця для самообслуговування, консультації щодо бізнесу (Дія. Бізнес), а також супутні послуги: безоплатна правова допомога, оплата комунальних послуг, дні та години прийому громадян головою територіальної громади, коворкінг-зони тощо. Також платформа Центрів Дія інформує про розвиток мережі Центрів, які послуги відвідувачі найчастіше замовляють та як облаштовані приміщення у Дія Центрах, все це громадянин може подивитися в онлайн режимі обравши для себе той суб'єкт надання адміністративних послуг, який йому підходить найбільше.

3 адміністративно-територіальними перетвореннями, передачею повноважень та бюджетів від державних органів на місця, реформуванням системи адміністративних послуг шляхом створення та вдосконалення роботи центрів надання адміністративних послуг - це все обумовило обрання нового вектору розвитку, який направлений на децентралізацію влади 3 максимальною передачею функцій на місцевий рівень. Наближення адміністративних послуг до громадян, їх 
доступність, висока якість, швидкість обслуговування стали однією 3 ключових функцій публічної влади.

На сьогодні публічна влада в Україні обрала вектор щодо надання якісних адміністративних послуг громадянам через сучасні ЦНАПи і активно розвиває даний напрям. Розвиток мережі Центрів надання адміністративних послуг це крок до запровадження цивілізованої, європейської системи взаємодії громадян та влади на шляху розбудови соціально-економічного потенціалу країни. Саме систематичний розвиток мережі ЦНАПів в Україні створює передумови до всеохоплюючої цифровізації державних послуг, завдяки цьому підвищується рівень обізнаності громадян про нові можливості, а також отримання вмінь щодо користування сучасними сервісами. Тому на сьогодні саме ЦНАПи є тим майданчиком, через які відбувається просування електронних послуг, підвищення цифрової грамотності населення та забезпечення фізичного доступу до послуг, що в підсумку створює цифрову державу та всеохоплюючу цифровізацію адміністративних послуг. У ході проведеного дослідження та враховуючи протиепідеміологічні заходи, які на сьогодні діють в країні у зв'язку з поширенням короновірусної хвороби з'ясовано, що слід поступово переходити до трасформаційних перетворень публічних інституцій і використання цифрових (електронних) послуг населенням, що дозволить тим самим сформувати безпечне середовище для клієнтів.

Шлях до перетворення України в «цифрову державу» $є$ не легким, адже зрозуміло, що для цього потрібно оцифрувати багато послуг, оновити законодавчу базу, систематизувати роботу державних реєстрів, забезпечити техніко-технологічні можливості та захист даних. Зміни повинні торкнутися не тільки сфери надання адміністративних послуг, а й галузей охорони здоров'я, бізнесу, освіти, транспорту, судів, питань демократії тощо.

\section{Література:}

1. Закон України «Про адміністративні послуги». URL: https:// zakon.rada.gov.ua/laws/show/5203-17 (дата звернення: 29.11.2021р.).

2. Міністерство цифрової трансформації України URL: https://thedigital.gov.ua/news/mintsifra-zapustit-natsionalnu-vebplatformutsentriv-nadannya-administrativnikh-poslug (дата звернення: 29.11.2021).

3. Про схвалення Концепції розвитку електронного урядування в Україні : розпорядження Кабінету Міністрів України від 20 вересня 2017 p. № 649-p URL: https://www.kmu.gov.ua/npas/250287124 (дата звернення: 29.11.2021р.) 
4. Пуліна Т. В., Шитікова Л. В., Риженко О. М. Удосконалення системи надання електронних послуг - ключова задача місцевого самоврядування. Державне управління: удосконалення та розвиток. 2020. № 11. - URL: http://www.dy.nayka.com.ua/?op=1\&z=1844 (дата звернення: 28.11.2021).

5. Стукан Т.М. Аналіз європейської системи інституційного забезпечення молодіжної політики. Фаховий науковий журналу «Вчені записки Таврійського начіонального університету імені В.I. Вернадського. Серія: Державне управління». Том 32 (71) № 4, 2021. С. 79-86. DOI https://doi.org/10.32838/TNU-2663-6468/2021.4/13.

6. Стукан Т.M. Термінологічний інструментарій дослідження дефініцій «державне управління» та «публічне управління». Вісник Національного університету иивільного захисту Украӥни. Серія: Державне управління. 2017. Вип. 2 (7). С. 462-468.

7. Stukan T. Mechanism of the formation of export potential of agricultural enterprises under conditions of european integration processes. East Journal of Security Studies, vol 3 (2018), pp. 286-298.

\title{
DOI https://doi.org/10.30525/978-9934-26-177-0-19
}

\section{ІНДИВІДУАЛЬНА ПРОГРАМА ПРОФЕСІЙНОГО РОЗВИТКУ ЯК ЗАСІБ ВИЗНАЧЕННЯ ІНДИВІДУАЛЬНИХ ПОТРЕБ ДЕРЖАВНОГО СЛУЖБОВЦЯ}

\author{
Юник I. Г. \\ кандидат наук з державного управління, доиент, \\ доцент кафедри публічного управління та адміністрування \\ Вінницького державного педагогічного університету \\ імені Михайла Кочюбинського \\ м. Вінниця, Украӥна
}

Сьогодні кожний державний службовець має право на професійне навчання та просування по службі 3 урахуванням професійної компетентності, а також зобов'язаний постійно підвищувати рівень своєї професійної компетентності та удосконалювати організацію службової діяльності. Відповідно до чинного законодавства всі державні службовці щороку складають індивідуальну програму професійного розвитку разом із службою управління персоналом на 